\title{
Climatic Factors, Reproductive SucCess AND POPUlation DYNAMICS IN THE MONTANE VOLE, MICROTUS MONTANUS
}

\author{
AELITA J. PINTER $\uparrow$ DEPARTMENT OF BIOLOGICAL SCIENCES \\ UNIVERSITY OF NEW ORLEANS $\uparrow$ LA
}

\begin{abstract}
$\downarrow$ OBJECTIVES
Multiannual fluctuations in population density ("cycles") of small rodents have been known since antiquity (Elton 1942). Numerous hypotheses have been proposed to explain this phenomenon (for reviews see Finerty 1980, Taitt and Krebs 1985). However, none of these hypotheses, alone or in combination, has been able to explain the causality of cycles, although recently removal of parasites was shown to prevent population cycles in the red grouse, Lagopus lagopus scoticus (Hudson et al. 1998).
\end{abstract}

The objectives of this long-term study are to determine whether environmental variables, possibly acting through reproductive responses, contribute to the multiannual fluctuations of the montane vole, Microtus montanus.

\section{$\uparrow \quad$ METHODS}

Microtus montanus were live trapped at two times of the year: the second half of May (spring study period) and mid-July to midAugust (summer study period). Animals were killed with an overdose of Metofane as soon as possible after capture. Animals were aged using weight, total length and pelage characteristics. The digestive tract and the liver were examined for the presence of parasites. Reproductive organs, the spleen and the adrenal glands were collected from all animals and preserved in
Lillie's buffered neutral formalin for further histological study. Flat skins were prepared from all animals.

Population density was estimated on the basis of the trapping success in a permanent grid (established in 1970). The grid consists of 121 stations placed in a square, $5 \mathrm{~m}$ apart, 11 stations $(50 \mathrm{~m})$ on a side. Each station is marked with a stake. Trapping in this grid was performed only during the summer study period. One unbaited Sherman livetrap was set at each station. Additional trapping was carried out in nearby meadows to obtain additional females for litter size determination. In these areas, traps were not set in a regular pattern; rather, they were placed only in locations showing recent vole activity (cuttings, droppings).

During the spring study period trapping was carried out in a number of sites, all well removed from the permanent grid. The objective of trapping during the spring study period was to determine (on the basis of embryo size) the onset of reproduction on a population-wide basis. The reason for not trapping the grid during the spring study period was to leave the site as undisturbed as possible since the grid is the major source of information on population density. In order to ascertain the effects of habitat/density on population dynamics of $M$. montanus in Grand Teton National Park, populations of these rodents were monitored in both, optimal and marginal habitats. 


\section{$\downarrow \quad$ RESUlTS AND DISCUSSION}

A relatively small population had overwintered in the study areas. At the onset of the spring study period there was very little current sign (runways, cuttings), furthermore, trap success was also low. However, there was potential for substantial population growth in 2001. In 2001, spring was relatively early and reproduction in $M$. montanus had also started early. Some of the females were pregnant with their first litter (they never had lactated), others were already pregnant with the second litter (lactating). Consequently, in 2001 the voles could produce an additional litter during their breeding season, resulting in significant consequences for population dynamics of these rodents. Early reproduction by the initial breeding population of the year not only adds individuals to the population, it also adds breeders. Voles born early in the year reproduce in the year of their birth (Pinter 1986, 1988); more importantly, females from the first litter begin breeding at 4-5 weeks of age (Negus, et. al. 1992).

By the end of the summer of 2001 the population density had risen above that of 2000 at all the study sites. However, this increase was not as large as had been anticipated at the end of the spring study period, especially in view of the early onset of breeding. Several factors clearly contributed to the unexpectedly modest increase in the numbers of voles. The summer of 2001 was very dry. As is the case in dry summers, there was a decrease in the amount of green forage, with a consequent slowing of the growth and maturation of the young of the year (Negus, et. al. 1992). Indeed, the delay in growth and maturation was so great that some of the animals born in 2001 (who would have ordinarily bred in the year of their birth) would probably not breed until the spring of 2002. The litter sizes of reproductively active animals also were small, furthermore, some of the formerly active breeders had stopped reproducing altogether (e.g., females were no longer pregnant, there was no sign of recent lactation). The developmental and reproductive responses exhibited by $M$. montanus during the summer of 2001 were an excellent example of the species' remarkable phenotypic plasticity (Negus \& Pinter, 1965).

At one of the study sites population cycles had become desynchronized from those at all other sites in 1998. In 2001, however, a resynchrony began as population density rose at all sites. Furthermore, an increase in population density of $M$. montanus resulted in a continued exclusion of $M$. pennsylvanicus from study areas where the two species occur sympatrically only when population density of $M$. montanus is low.

\section{$\downarrow$ CONCLUSIONS}

Although the drought in the summer of 2001 curtailed growth and reproductive activity of $M$. montanus, the population density rose above that recorded in the summer of 2000. Two factors contributed to this phenomenon. First, the initial breeding population was larger in the spring of 2001. However, the summer drought curtailed the growth and maturation of the young of the year and suppressed reproduction in the population as a whole. These findings demonstrate that (a) voles are extremely sensitive to environmental factors, (b) their sensitivity to such factors is characterized by remarkably rapid physiological responses, and (c) environmental factors, mediated via physiological responses, have a prompt effect on population dynamics of these rodents. However, since a large number of environmental factors is involved, only longterm studies will be able to discern the factors in question and their relative contribution to population dynamics.

\section{ACKNOWLEDGEMENTS}

I gratefully acknowledge the availability of the facilities at the University of WyomingNational Park Service Research Center and the enthusiastic support of the Research Center staff without which it would have been impossible to accomplish this work. I am particularly grateful to the Steering Committee of the UW-NPS Research Center and to the National Park Service for their cognizance of the fact that the understanding of microtine cycles can be gained only from long-term studies.

\section{Literature Cited}

Elton, C.S. 1942. Voles, mice and lemmings. Clarendon Press, Oxford. 496 pp. 
Finerty, J.P. 1980. The Population Ecology of Cycles in Small Mammals. Mathematic Theory and Biological Fact. Yale Univ. Press, New Haven. 234 pp.

Hudson, P.J., A.P. Dobson and D. Newborn. 1998. Prevention of population cycles by parasite removal. Science, 282: 22562258.

Negus, N.C., P.J. Berger, and A.J. Pinter. 1992. Phenotypic plasticity of the montane vole (Microtus montanus) in unpredictable environments. Can. J. Zool. 70:21212124.

Negus, N.C. and A.J. Pinter. 1965. Litter sizes of Microtus montanus in the laboratory. J. Mammal. 46: 434-437.
Pinter, A.J. 1986. Population dynamics and litter size of the montane vole, Microtus montanus. Can J. Zool. 64:1487-1490.

Pinter, A.J. 1988. Multiannual fluctuations in precipitation and population dynamics of the montane vole, Microtus montanus. Can. J. Zool. 66:2128-2132.

Taitt, M.J. and C.J. Krebs. 1985. Population dynamics and cycles $\underline{I n}$ : Biology of New World Microtus. R.H. Tamarin, ed. Spec. Publ. Amr. Soc. Mannual. 8:567-620. 